\title{
Analysis of Rainfall Data for Drought Investigation at Mungeli of Chhattisgarh Plain
}

\author{
B.L. Sinha*
}

DKS College of Agriculture and Research Station, Indira Gandhi Krishi Vishvavidyalaya Khapardih, Bhtapara, District-Balaudabazar, Chhattisgarh (India) -493118

*Corresponding author

\begin{tabular}{|l|}
\hline Ke y w o r d s \\
Drought, Rainfall, \\
Mungeli \\
\hline Article Info \\
\hline $\begin{array}{l}\text { Accepted: } \\
\text { 20 February } 2019 \\
\text { Available Online: } \\
\text { 10 March } 2019\end{array}$ \\
\hline
\end{tabular}

\section{A B S T R A C T}

Drought analysis offers a better scope for predicting the occurrence of drought to help in crop planning in rainfed regions. In view of this, an attempt has been made to evaluate drought reoccurrence patterns of weekly, seasonal, monthly and annual rainfall according to the severity, based on 17 years (2000-2016) data of Mungeli, Chhattisgarh. The observed data shows that $38^{\text {th }}$ and $39^{\text {th }}$ standard meteorological week experienced maximum $(58.82 \%)$ disaster drought and followed by SMW $24^{\text {th }}$ and $26^{\text {th }}$. It was also observed that no drought condition was experienced maximum 52.94 in SMW $32^{\text {nd }}$.From the monthly rainfall analysis, it was found that June, July August and September months of monsoon season experienced 5.88, 35.29, 35.29 and $17.64 \%$ mild drought. Moreover, it is experienced that maximum disaster drought $(88.23 \%)$ in the December month while August month did not experienced any disaster drought. The climatic seasonal analysis depicts that the monsoon season experienced 58.82, 29.011 .76 and $0 \%$ of no drought, mild, severe and disastrous drought, respectively. The kharif and monsoon season of the region are experienced zero percent disastrous drought and they have 41.1 and $58.8 \%$ of occurrence possibility of no drought condition thus in these seasons rain water is sufficient for crop planning, but there is frequent drought in region. The severe drought is experienced in the year 2000 and 2016. Therefore, 07 out of 17 years (years 2006, 2008, 2009, 2010, 2011, 2012 and 2015) experienced mild drought years for the 7 years. There was a continuous drought from 2008 to 2012 and 2015 to16. Thus some major steps are needed for assuring the irrigation in rainfed regions. Also the possibilities of occurrence of drought are high in rest of the seasons and as observed every year more than $75 \%$ of the rainfall occurs in the monsoon season, so there is a need of water harvesting at the time of monsoon season for crop planning of rabi season for at least one or two supplemental irrigations.

\section{Introduction}

Rainwater is the single most important potential source of moisture/water for agricultural farming system. Rainfall determines the potential of any region in terms of crops to be produced, farming system to be adopted, the nature and sequence of farming operation to be followed and to achieve higher agricultural productivity as well. Rainfall is a randomly distributed hydrological event. It varies with space and 
time. The knowledge of total rainfall and its distribution pattern round the year of a place is very important for better crop planning, determining irrigation and drainage requirement of crops, design and construction of soil and water conservation structures. In rainfed agriculture, the total amount of rainfall as well as its distribution affects the plant growth (Chkraborty and Mondal, 2008).

Drought is normal recurring climatic phenomena that vary in space, time, and intensity. Drought is one of the most serious problems for human societies and ecosystems. It gradually establishes with the negative anomaly of rainfall for a required period and it is one of the most damaging types of natural disaster over long periods. It is necessary to know about the timing, locations, severity, and pattern of droughts for effective planning and decision making. This information helps officials and farmers to be more proactive in managing drought risks. Impacts of drought can be reduced through better understanding and identifying the appropriate drought indicators for an early warning system. It is being monitored by computing indices based on rainfall and many other parameters. In the last few decades, several drought indices have been developed based on several parameters, the details of which can be found in Heim (2002), Mishra and Singh (2010), Dai (2011), Pandey et al., (2014). Keeping this in view, an attempt has been made to evaluate drought reoccurrence patterns of weekly, seasonal, monthly and annual rainfall according to the severity, based on 16 years (2000-2015) data of Mungeli, Chhattisgarh plain.

\section{Materials and Methods}

Mungeli was formed as tahsil in 1860. It is now newly formed district came into being on 1st January, 2012. The district consists of 3 administrative blocks/tehsils namely Mungeli, Patharia and Lormi and total numbers of villages in the district are 711 (Fig. 1). It is situated between latitudes $21^{0} 48^{\prime} 35^{\prime \prime}$ to $22^{0}$ $40^{\prime} 30^{\prime \prime}$ and longitudes $81^{\circ} 29^{\prime} 45^{\prime \prime}$ to $82^{\circ} 02^{\prime}$ 10 ". It is bounded by Bilaspur on the north and east, Anuppur and Dhindori district of Madhya Pradesh on the north, Kabirdham on the west, Bemetara district on the south and Baloda Bazar on the south-east. The area of the district is about $2750.36 \mathrm{~km}^{2}$. Mungeli has a tropical wet and dry climate, temperatures remain moderate throughout the year, except from March to June, which can be extremely hot. The winter commences from November and last till the end of February. The summer season beings from March and continues till the second week of June. Monsoon season commences from middle of June and remains till the end of the September.

The daily rainfall data of the study area was collected from Tehsil office Mungeli. This was a 24 hours rainfall data measured with the help of non-recording and recording type rain gauge installed in nearby area. The daily rainfall data pertains to a period of past 17 years, viz. 2000 - 2016. Weekly rainfall data, monthly, seasonally and annually were obtained by summing up the daily rainfall values as per recommendation of IMD. The rainfall characteristic of the region was analyzed by Sinha et al., 2017.

\section{Drought analysis}

Meteorological drought is defined usually on the basis of the degree of dryness (in comparison to some normal or average amount). According to IMD, meteorological drought is defined as occurring when the seasonal rainfall received over an area is less than $75 \%$ of its long period average value. It is further classified as 'moderate drought', if the rain fall deficit is within the range of 25 to $50 \%$ and 'severe drought' if departure exceeds 50\% (Pander et al., 2014). The method used by the IMD is a simple 
procedure which assesses the drought on the basis of percentage deviation of actual rainfall (Pi) from the long term mean rainfall $\left(\mathrm{P}_{\mathrm{m}}\right)$. The percentage deviation $\left(D_{i}\right)$ is given by

$\mathrm{Di}=\left[\left(\mathrm{P}_{\mathrm{i}}-\mathrm{P}_{\mathrm{m}}\right) / \mathrm{P}_{\mathrm{m}}\right] \times 100$

The percentage deviation of rainfall and the category of drought assessment are as given in Table 1.

\section{Percentage occurrence of drought}

It can be defined as number of event occurs divided by total number of record and multiplied by hundred.

\section{Results and Discussion}

The analysis of rainfall data of 17 years (2000-2016) of Mungeli, Chhattisgarh have been analyzed to evaluate drought reoccurrence patterns of weekly, seasonal, monthly and annual rainfall according to the severity and described below under different section.

\section{Weekly drought analysis}

The weekly occurrence of drought was predicted using the equation of percentage deviation and is presented in Table 2 and shown Figure 2.

This prediction helps to optimize choice of crops, sowing date and irrigation scheduling of different crops to be cultivated and efficient use of rainwater in rainfed areas for getting maximum production. In weekly drought analysis it mainly considered the monsoon season weeks $\left(24^{\text {th }}\right.$ to $\left.39^{\text {th }}\right)$. SMW 38 and 39 experienced maximum $(58.82 \%)$ disaster drought and followed by SMW 24 and 26. Out of 17 years of the study, severe drought was experienced maximum 4 times in the SWM 31 and 33 while the mild drought was experienced maximum 5 times in SMW 34.

It was also observed that no drought condition was experienced maximum 52.94 in SMW $32^{\text {nd }}$. This analysis shows there is wide variations in quantitative measures which indicates that the rainfall received in region are highly erratic.

\section{Monthly drought analysis}

The average monthly rainfall and drought occurrences during individual months are determined for 17 years period and monthwise distribution of no drought, mild drought, severe drought and disastrous drought is presented in Table 3.

Out of 17 years period, drought occurrences of 9 years are observed in the Mungeli region. It can be observed from the Figure 3 that 5.88, $35.29,35.29$ and $17.64 \%$ mild drought were occurred in the month June, July August and September of monsoon season, respectively. It emphasizes the severity of drought in Mungeli region.

Moreover, it is experienced that maximum disaster drought $(88.23 \%)$ in the December month while August month did not experienced any disaster drought. Maximum $(17.64 \%)$ severe drought was experienced in the month of April and July.

A major part of rainfall in the month of July and August generally lost through runoff, which can be stored through in-situ or ex- situ water harvesting structures and used during kharif / rabi / zaid season for growing crops.

It can also be utilized as life saving irrigation particularly in dry period of one or two weeks in rainy season also adversely affect standing kharif crops in the region. 


\section{Seasonal drought analysis}

\section{Climatic seasonal drought analysis}

On the basis of mean seasonal rainfall it can be observed that monsoon season receives $75 \%$ of total rainfall of the year. It is clear from the Figure 4 that the monsoon season experienced $58.82 \%$ of no drought condition, $29 \%$ of mild drought conditions, $11.76 \%$ of severe drought conditions and $0 \%$ of disastrous drought conditions presented in Table 4. Hence this would be helpful for collection of surface runoff during this rainy season and efficient use of harvested rainwater during the subsequent dry period of winter, summer season. It was also found that the occurrences of no drought, mild drought, severe drought and disastrous drought conditions in summer / pre monsoon season were $58.82,17.64 \%, 11.76 \%$ and $35.29 \%$, respectively. Post monsoon and winter season experienced maximum $35.29 \%$ and $41.17 \%$ disaster drought and no any drought respectively. Hence distribution rainfall is uneven and erratic.

\section{Cropping seasonal drought analysis}

In cropping seasonal analysis of rainfall for investigation of drought, it is clear that $75 \%$ total of rainfall of the year has been received in the kharif season. It was observed that $41.17 \%$ of no drought condition, $41.17 \%$ of mild drought conditions, $11.76 \%$ of severe drought conditions and $0 \%$ of disastrous drought conditions were occurred in the kharif season shown in Figure 5.

The excess rainfall during the Kharif season would be scope to harvest excess amount of rainwater and recycling of harvested rainwater as life saving irrigation at critical stages of crop growth during dry periods. The occurrences of no drought, mild drought, severe drought and disastrous drought conditions in zaid season were $47.05 \%, 23.52$ $\%, \quad 11.76 \%$ and $17.64 \%$, respectively presented in Table 4 while in Rabi season $47.05 \%, 5.88 \%, 11.76 \%$ and $35.29 \%$ occurred no drought, mild drought, severe drought and disastrous drought condition. Hence there was no any pattern occurrence of drought in the region.

\section{Annual drought analysis}

The average annual rainfall for Mungeli region is about $1089.08 \mathrm{~mm}$ on the basis of 17 years (2000-2017). A plot showing the percentage deviation of the annual rainfall over 17 years is depicted in Figure 6 and which indicates that the rainfall in the region is highly variable and erratic. A Meteorological drought is occurred if the rainfall of the area deficit from 0 to $25 \%$. Thus, it can be seen that the occurrences of no drought, mild drought and severe drought conditions were $47.05,1.17$ and $11.76 \%$, respectively and no year faced disastrous drought condition during study period.

Table.1 Classification of drought by

\begin{tabular}{|l|l|l|}
\hline S. No. & Condition & Class Drought category \\
\hline $\mathbf{1}$ & $\mathrm{Di}>0$ & No Drought \\
\hline $\mathbf{2}$ & $0>\mathrm{Di}>-25$ & Mild Drought \\
\hline $\mathbf{3}$ & $-25>\mathrm{Di}>-50$ & Severe Drought \\
\hline $\mathbf{4}$ & $\mathrm{Di}<-50$ & Disastrous Drought \\
\hline
\end{tabular}

Note : $\mathrm{Dj}$ is the percentage deviation of rainfall from mean rainfall 
Table.2 Weekly drought occurrence during the period of 2000-2017

\begin{tabular}{|c|c|c|c|c|c|c|c|c|}
\hline SMW & \multicolumn{2}{|c|}{ No Drought } & \multicolumn{2}{c|}{ Mild Drought } & \multicolumn{2}{c|}{ Severe Drought } & \multicolumn{2}{|c|}{$\begin{array}{c}\text { Disastrous } \\
\text { Drought }\end{array}$} \\
\cline { 2 - 9 } & $\begin{array}{c}\text { No. of } \\
\text { weeks }\end{array}$ & $\begin{array}{c}\text { Occurrence } \\
(\%)\end{array}$ & $\begin{array}{c}\text { No. } \\
\text { of } \\
\text { weeks }\end{array}$ & $\begin{array}{c}\text { Occurrence } \\
(\%)\end{array}$ & $\begin{array}{c}\text { No. } \\
\text { of } \\
\text { weeks }\end{array}$ & $\begin{array}{c}\text { Occurrence } \\
(\%)\end{array}$ & $\begin{array}{c}\text { No. } \\
\text { of } \\
\text { weeks }\end{array}$ & $\begin{array}{c}\text { Occurrence } \\
(\%)\end{array}$ \\
\hline $\mathbf{2 4}$ & 6 & 35.29 & 0 & 0 & 2 & 11.76 & 9 & 52.94 \\
\hline $\mathbf{2 5}$ & 7 & 41.17 & 0 & 0 & 3 & 17.64 & 7 & 41.17 \\
\hline $\mathbf{2 6}$ & 7 & 41.17 & 1 & 5.88 & 1 & 5.88 & 8 & 47.05 \\
\hline $\mathbf{2 7}$ & 8 & 47.05 & 3 & 17.64 & 2 & 11.76 & 4 & 23.52 \\
\hline $\mathbf{2 8}$ & 9 & 52.94 & 1 & 5.88 & 1 & 5.88 & 6 & 35.29 \\
\hline $\mathbf{2 9}$ & 8 & 47.05 & 2 & 11.76 & 3 & 17.64 & 4 & 23.52 \\
\hline $\mathbf{3 0}$ & 6 & 35.29 & 4 & 23.52 & 2 & 11.76 & 5 & 29.41 \\
\hline $\mathbf{3 1}$ & 7 & 41.17 & 0 & 0 & 4 & 23.52 & 6 & 35.29 \\
\hline $\mathbf{3 2}$ & 9 & 52.94 & 3 & 17.64 & 0 & 0 & 5 & 29.41 \\
\hline $\mathbf{3 3}$ & 7 & 41.17 & 3 & 17.64 & 4 & 23.52 & 3 & 17.64 \\
\hline $\mathbf{3 4}$ & 7 & 41.17 & 5 & 29.41 & 0 & 0 & 5 & 29.41 \\
\hline $\mathbf{3 5}$ & 7 & 41.17 & 1 & 5.88 & 3 & 17.64 & 6 & 35.29 \\
\hline $\mathbf{3 6}$ & 8 & 47.05 & 3 & 17.64 & 1 & 5.88 & 5 & 29.41 \\
\hline $\mathbf{3 7}$ & 5 & 29.41 & 2 & 11.76 & 3 & 17.64 & 7 & 41.17 \\
\hline $\mathbf{3 8}$ & 5 & 29.41 & 0 & 0 & 2 & 11.76 & 10 & 58.82 \\
\hline $\mathbf{3 9}$ & 6 & 35.29 & 1 & 5.88 & 0 & 0 & 10 & 58.82 \\
\hline
\end{tabular}

Table.3 Monthly drought occurrence during the period of 2000-2017

\begin{tabular}{|l|c|c|c|c|c|c|c|c|}
\hline Months & \multicolumn{2}{|c|}{ No Drought } & \multicolumn{2}{c|}{ Mild Drought } & \multicolumn{2}{c|}{ Severe Drought } & \multicolumn{2}{|c|}{$\begin{array}{c}\text { Disastrous } \\
\text { Drought }\end{array}$} \\
\cline { 2 - 10 } & $\begin{array}{c}\text { No. of } \\
\text { months }\end{array}$ & $\begin{array}{c}\text { Occurrence } \\
(\%)\end{array}$ & $\begin{array}{c}\text { No. of } \\
\text { months }\end{array}$ & $\begin{array}{c}\text { Occurrence } \\
(\%)\end{array}$ & $\begin{array}{c}\text { No. of } \\
\text { months }\end{array}$ & $\begin{array}{c}\text { Occurrence } \\
(\%)\end{array}$ & $\begin{array}{c}\text { No. of } \\
\text { months }\end{array}$ & $\begin{array}{c}\text { Occurrence } \\
(\%)\end{array}$ \\
\hline Jan & 6 & 35.29 & 0 & 0 & 1 & 5.88 & 10 & 58.82 \\
\hline Feb & 10 & 58.82 & 0 & 0 & 2 & 11.76 & 5 & 29.41 \\
\hline Mar & 8 & 47.05 & 2 & 11.76 & 0 & 0 & 7 & 41.17 \\
\hline Apr & 5 & 29.41 & 0 & 0 & 3 & 17.64 & 9 & 52.94 \\
\hline May & 7 & 41.17 & 0 & 0 & 0 & 0 & 10 & 58.82 \\
\hline Jun & 10 & 58.82 & 1 & 5.88 & 1 & 5.88 & 5 & 29.41 \\
\hline Jul & 7 & 41.17 & 6 & 35.29 & 3 & 17.64 & 1 & 5.88 \\
\hline Aug & 9 & 52.94 & 6 & 35.29 & 2 & 11.76 & 0 & 0 \\
\hline Sept & 8 & 47.05 & 3 & 17.64 & 2 & 11.76 & 4 & 23.52 \\
\hline Oct & 5 & 29.41 & 2 & 11.76 & 1 & 5.88 & 9 & 52.94 \\
\hline Nov & 5 & 29.41 & 0 & 0 & 0 & 0 & 12 & 70.58 \\
\hline Dec & 2 & 11.76 & 0 & 0 & 0 & 0 & 15 & 88.23 \\
\hline
\end{tabular}


Table.4 Seasonally and yearly drought occurrence during the period of 2000-2017

\begin{tabular}{|c|c|c|c|c|c|c|c|c|}
\hline \multirow[t]{2}{*}{ Season } & \multicolumn{2}{|c|}{ No Drought } & \multicolumn{2}{|c|}{ Mild Drought } & \multicolumn{2}{|c|}{ Severe Drought } & \multicolumn{2}{|c|}{$\begin{array}{c}\text { Disastrous } \\
\text { Drought }\end{array}$} \\
\hline & $\begin{array}{c}\text { No. of } \\
\text { seasons }\end{array}$ & $\begin{array}{c}\text { Occurrence } \\
(\%)\end{array}$ & $\begin{array}{c}\text { No. of } \\
\text { seasons }\end{array}$ & $\begin{array}{c}\text { Occurrence } \\
(\%)\end{array}$ & $\begin{array}{c}\text { No. of } \\
\text { seasons }\end{array}$ & $\begin{array}{c}\text { Occurrence } \\
(\%)\end{array}$ & $\begin{array}{c}\text { No. of } \\
\text { seasons }\end{array}$ & $\begin{array}{c}\text { Occurrence } \\
(\%)\end{array}$ \\
\hline \multicolumn{9}{|c|}{ Climatic Season } \\
\hline Summer & 6 & 35.29 & 3 & 17.64 & 2 & 11.76 & 6 & 35.29 \\
\hline Monsoon & 10 & 58.82 & 5 & 29.41 & 2 & 11.76 & 0 & 0 \\
\hline $\begin{array}{l}\text { Post } \\
\text { Monsoon }\end{array}$ & 6 & 35.29 & 3 & 17.64 & 2 & 11.76 & 6 & 35.29 \\
\hline Winter & 7 & 41.17 & 2 & 11.76 & 1 & 5.88 & 7 & 41.17 \\
\hline \multicolumn{9}{|c|}{ Cropping season } \\
\hline Zaid & 8 & 47.05 & 4 & 23.52 & 2 & 11.76 & 3 & 17.64 \\
\hline Kharif & 7 & 41.17 & 7 & 41.17 & 3 & 17.64 & 0 & 0 \\
\hline Rabi & 8 & 47.05 & 1 & 5.88 & 2 & 11.76 & 6 & 35.29 \\
\hline \multicolumn{9}{|l|}{ Yearly } \\
\hline Annual & 8 & 47.05 & 7 & 41.17 & 2 & 11.76 & 0 & 0 \\
\hline
\end{tabular}

Fig.1 Map of Mungeli district of CG

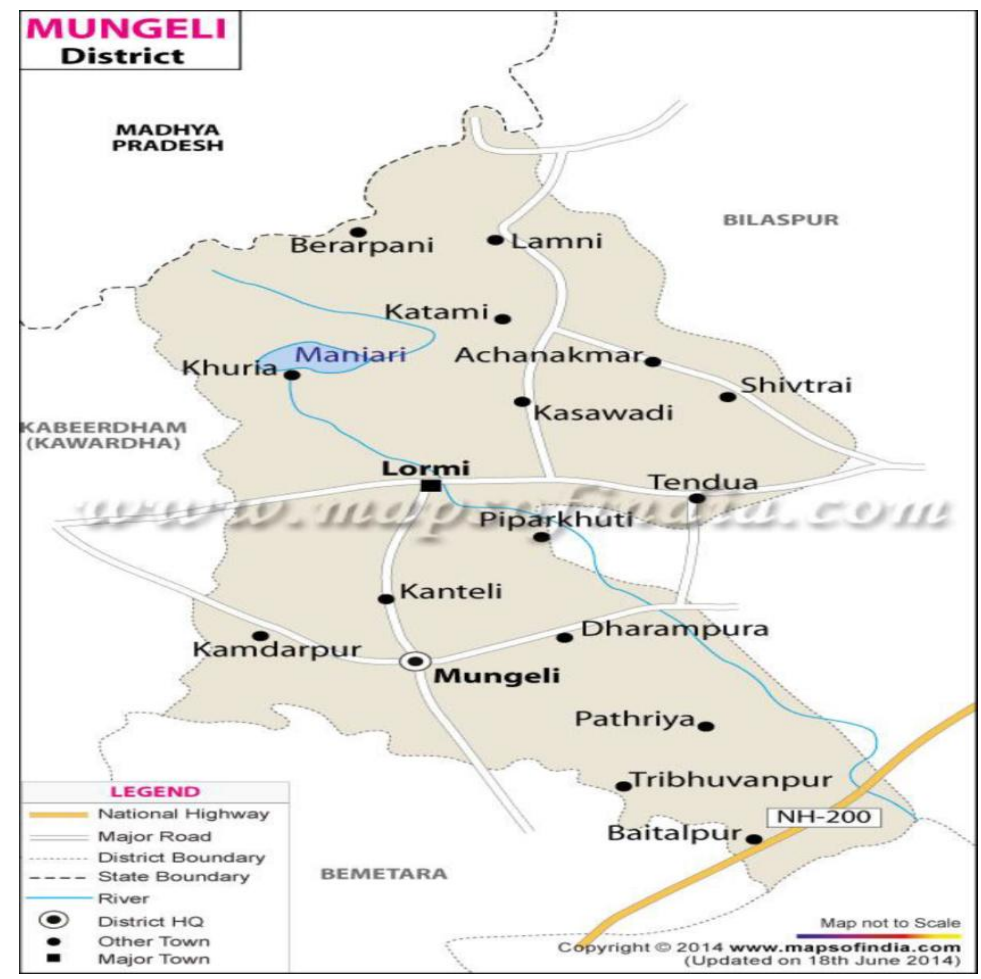




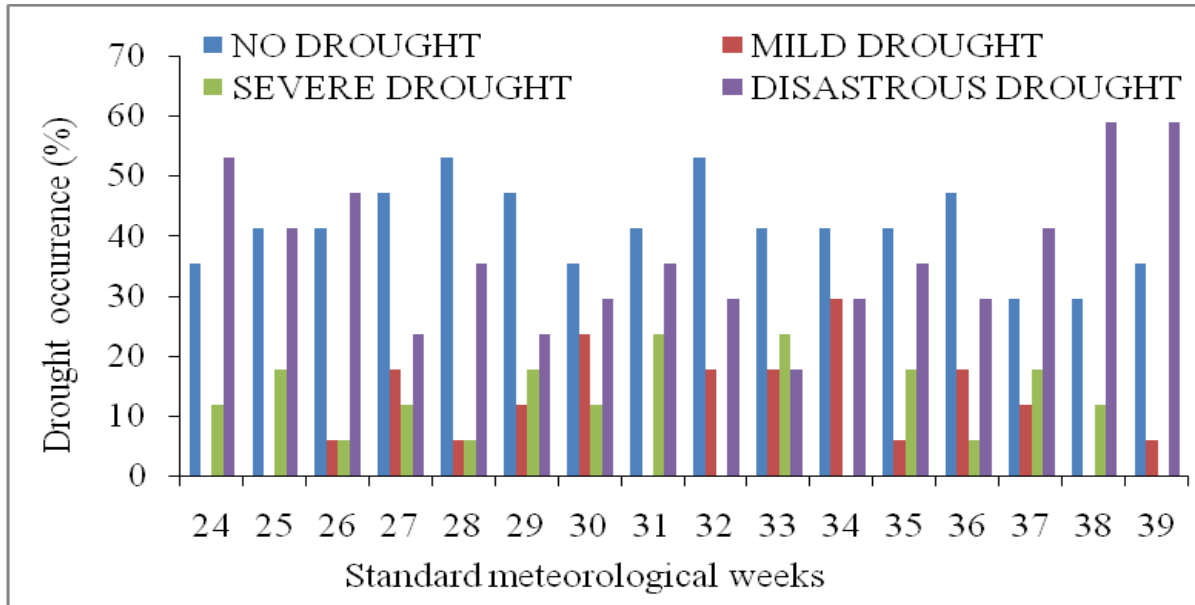

Fig. 2: Occurrence of weekly drought
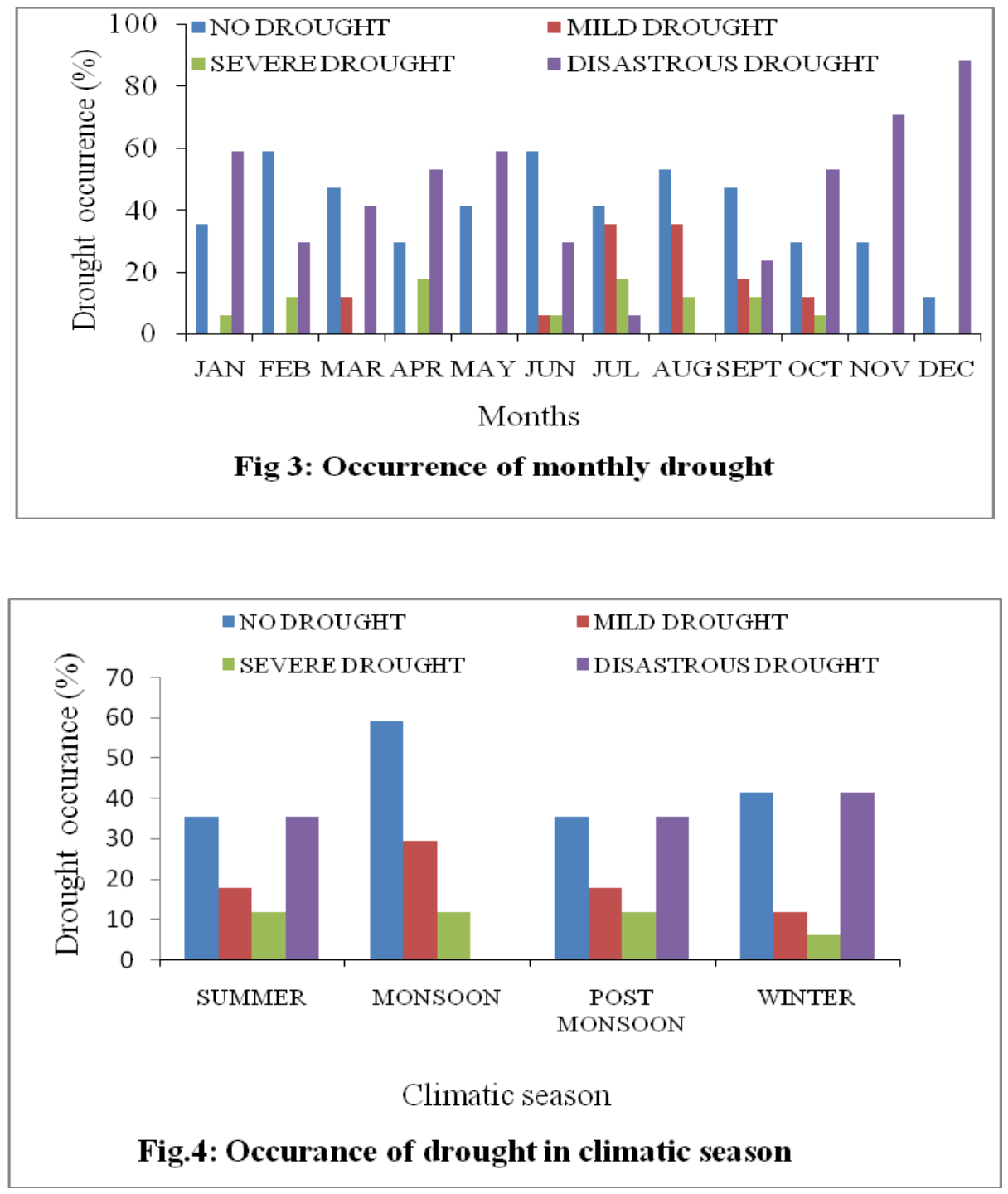

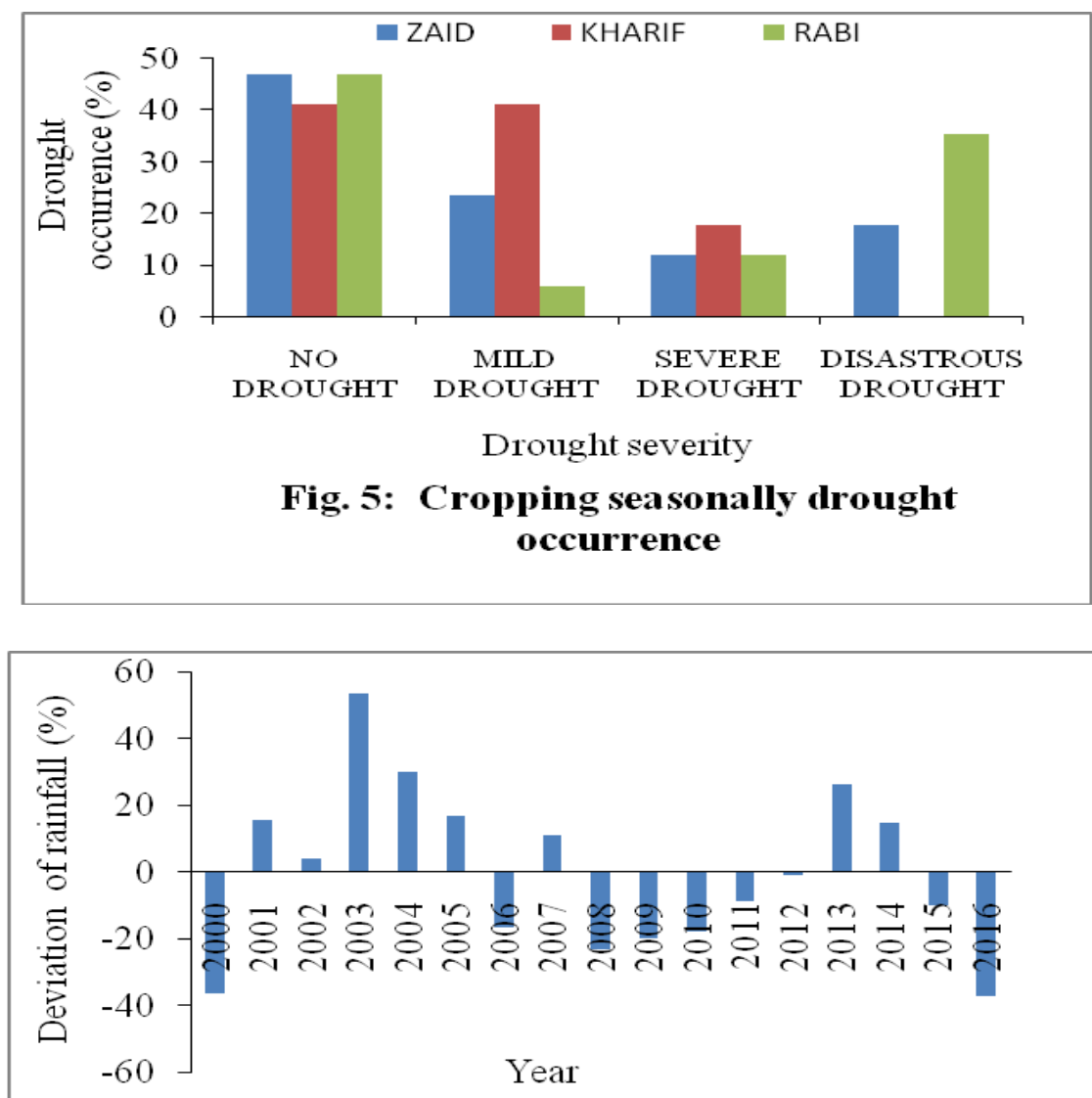

Fig. 6: Yearly percentage deviation of rainfall

The severe drought is experienced in 2000 ($36.04 \%$ deviation of rainfall) and 2016 ($37.27 \%$ deviation of rainfall). Any year receiving rainfall with deviation from 0 to $25 \%$ will be the year with facing mild drought. Therefore, 07 out of 17 years (years 2006, 2008, 2009, 2010, 2011, 2012 and 2015) should be mild drought years for the 7 years. The year 2012 experienced least mild drought as $-1.00 \%$ deviation of rainfall was observed. It was also found that 9 years i.e.2000, 2006, 2008, 2009, 2010, 2011, 2012, 2015 and 2016 were observed as drought years. There was a continuous drought from 2008 to 2012 and 2015 to16. Years receiving rainfall with percentage deviation more than zero will be years with facing no drought. Therefore, remaining 8 out of 17 years should be no drought years. Hence it is observed that drought is a recurrent phenomenon in
Mungeli region and mostly, it occurs during non-monsoon period.

In conclusion, if proper and detailed study of various rainfall data is analyzed, the severity and reoccurrence of droughts can be known beforehand. Thus various measures can be taken to cope up with the problems of drought. In a present study of Mungeli region of Chhattisgarh plain drought analysis based on 17 years was observed. The observed data shows that $38^{\text {th }}$ and $39^{\text {th }}$ standard meteorological week experienced maximum $(58.82 \%)$ disaster drought and followed by SMW $24^{\text {th }}$ and $26^{\text {th }}$. It was also observed that no drought condition was experienced maximum 52.94 in SMW 32 ${ }^{\text {nd }}$. June, July August and September months of monsoon season experienced 5.88, 35.29, 35.29 and $17.64 \%$ mild drought. It emphasizes the 
severity of drought in Mungeli region. Moreover, it is experienced that maximum disaster drought $(88.23 \%)$ in the December month while August month did not experienced any disaster drought. The climatic seasonal analysis depicts that the monsoon season experienced 58.82, 29.0 11.76 and $0 \%$ of no drought, mild, severe and disastrous drought, respectively while post monsoon and winter season experienced maximum $35.29 \%$ and $41.17 \%$ disaster drought and no any drought, respectively. It was observed that $41.17 \%$ of no drought condition, $41.17 \%$ of mild drought conditions, $11.76 \%$ of severe drought conditions and $0 \%$ of disastrous drought conditions were occurred in the kharif season on the basis of cropping season. The severe drought is experienced in $2000(-36.04 \%$ deviation of rainfall) and $2016(-37.27 \%$ deviation of rainfall). Therefore, 07 out of 17 years (years 2006, 2008, 2009, 2010, 2011, 2012 and 2015) should be mild drought years for the 7 years. The year 2012 experienced least mild drought as $1.00 \%$ deviation (negative) of rainfall was observed. It was also found that 9 years i.e.2000, 2006, 2008, 2009, 2010, 2011, 2012, 2015 and 2016 were observed as drought years. There was a continuous drought from 2008 to 2012 and 2015 to16.

The results of the present study indicate that drought is a recurrent phenomenon in Mungeli region and mostly, it occurs during non-monsoon period. Accordingly, it is suggested to develop and implement suitable water harvesting measures in the region to store the excess runoff water during monsoon season. Consequently, with this stored water supplemental irrigation can be provided to save the crops during moisture deficit period of post monsoon and summer seasons. The present information can be helpful for planning the optimal cropping pattern and deciding time of different agricultural operations in the region.

\section{References}

Chakraborty, P. B. and Mandal, A. P. N. 2008. Rainfall characteristics of Sagar island in Sundarban, West Bengal, Indian journal of soil conservation, 36 (3): 125-128.

Dai A. 2011. Drought under global warming: a review; Clim Change 2: 45-65.

Heim R. R. 2002. A review of twentieth century drought indices used in the United States; Bull. Am. Meteorol. Soc. 83: 1149-1165.

Mishra A.K., Singh V.P. 2010. A review of drought concepts; J. Hydrol. 391: 202-216.

Pandey Swati, Kumar Manoj and Mahanti N.C. 2014. Assessment of Drought Severity in Various Regions of Jharkhand State of India. Int. Res. J. Environment Sci. Vol. 3(2), 8-14.

Sinha B. L., Sahu R. K., Pradhan M.K. and Sinha J. 2017. Evaluation of Rainfall Distribution Pattern for Agricultural Planning in Mungeli District of Chhattisgarh Plain. Proceeding of Asian conference on Water and Land Management for Food and Livelihood Security" Asian conference held at IGKV, Raipur on January 20-22, 2017.

\section{How to cite this article:}

Sinha, B.L. 2019. Analysis of Rainfall Data for Drought Investigation at Mungeli of Chhattisgarh Plain. Int.J.Curr.Microbiol.App.Sci. 8(03): 2255-2263. doi: https://doi.org/10.20546/ijcmas.2019.803.269 